WM '03 Conference, February 23-27, 2003, Tucson, AZ

\title{
STEAM REFORMING TECHNOLOGY FOR DENITRATION AND IMMOBILIZATION OF DOE TANK WASTES
}

\author{
J. Bradley Mason, John McKibbin, Kevin Ryan, and Duane Schmoker \\ THOR Treatment Technologies, LLC \\ 1135 Jadwin, Richland, WA 99352
}

\begin{abstract}
THOR Treatment Technologies, LLC (THOR) is a joint venture formed in June 2002 by Studsvik, Inc. (Studsvik) and Westinghouse Government Environmental Services Company LLC to further develop, market, and deploy Studsvik's patented THOR ${ }^{\mathrm{SM}}$ non-incineration, steam reforming waste treatment technology. This paper provides an overview of the THOR ${ }^{\mathrm{SM}}$ steam reforming process as applied to the denitration and conversion of Department of Energy (DOE) tank wastes to an immobilized mineral form.
\end{abstract}

Using the THOR ${ }^{\mathrm{SM}}$ steam reforming technology to treat nitrate containing tank wastes could significantly benefit the DOE by reducing capital and life-cycle costs, reducing processing and programmatic risks, and positioning the DOE to meet or exceed its stakeholder commitments for tank closure. Specifically, use of the $\mathrm{THOR}^{\mathrm{SM}}$ technology can facilitate processing of up to $75 \%$ of tank wastes without the use of vitrification, yielding substantial life-cycle cost savings.

Tank wastes are composed of a wide range of radioactive salt cakes and supernatant solutions that contain high concentrations of sodium, aluminum, nitrates, nitrites, hydroxides, and sulfates with significant concentrations of chlorides, fluorides, heavy metals, radionuclides, and most other inorganic elements as well. The $\mathrm{THOR}^{\mathrm{SM}}$ steam reforming process has been proven to efficiently immobilize the radionuclides, sodium, sulfates, chlorides, fluorides and non-volatile heavy metals into a stable, water insoluble mineral matrix. The leaching resistance of the mineral product exceeds the performance of most borosilicate glasses (1).

In the $\mathrm{THOR}^{\mathrm{SM}}$ process, waste feed, superheated steam, and co-reactants are introduced into a steam reformer vessel where liquids are evaporated, organics are destroyed, and reactive chemicals in the waste feed are fully converted to a stable waste product that incorporates essentially all of the radionuclides. The fluidized bed design of the steam reformer provides a large surface area for the waste to fully and efficiently react. Carbon and iron-based co-reactants (reductants) are used to convert nitrates and nitrites directly to nitrogen gas in the reformer. Clay or other inorganic co-reactants are added to the waste feed or bed to convert the radionuclides, alkali metals (sodium and potassium), sulfate, chloride, fluoride and non-volatile heavy metals into an immobilized mineral product. The process operates safely under vacuum and at moderate temperatures $\left(700-750^{\circ} \mathrm{C}\right)$.

The steam reforming process destroys RCRA and TSCA organic constituents. Toxic organics are converted to carbon dioxide and water vapor in the steam reformer by a combination of steam reforming and oxidizing reactions.

(C) THOR Treatment Technologies, LLC, 2002. All Rights Reserved Published with the express permission of THOR Treatment Technologies. 
Off-gases from the steam reformer vessel are treated by wet scrubber technology to neutralize minor amounts of corrosive acid gases and particulates that are carried out of the reforming vessel with the off-gas. The off-gases are cooled, scrubbed, and passed through a HEPA filter so that the primary emissions released to the atmosphere from the process are carbon dioxide and water vapor. A simplified flow diagram of the steam reforming process is provided in Figure 1.

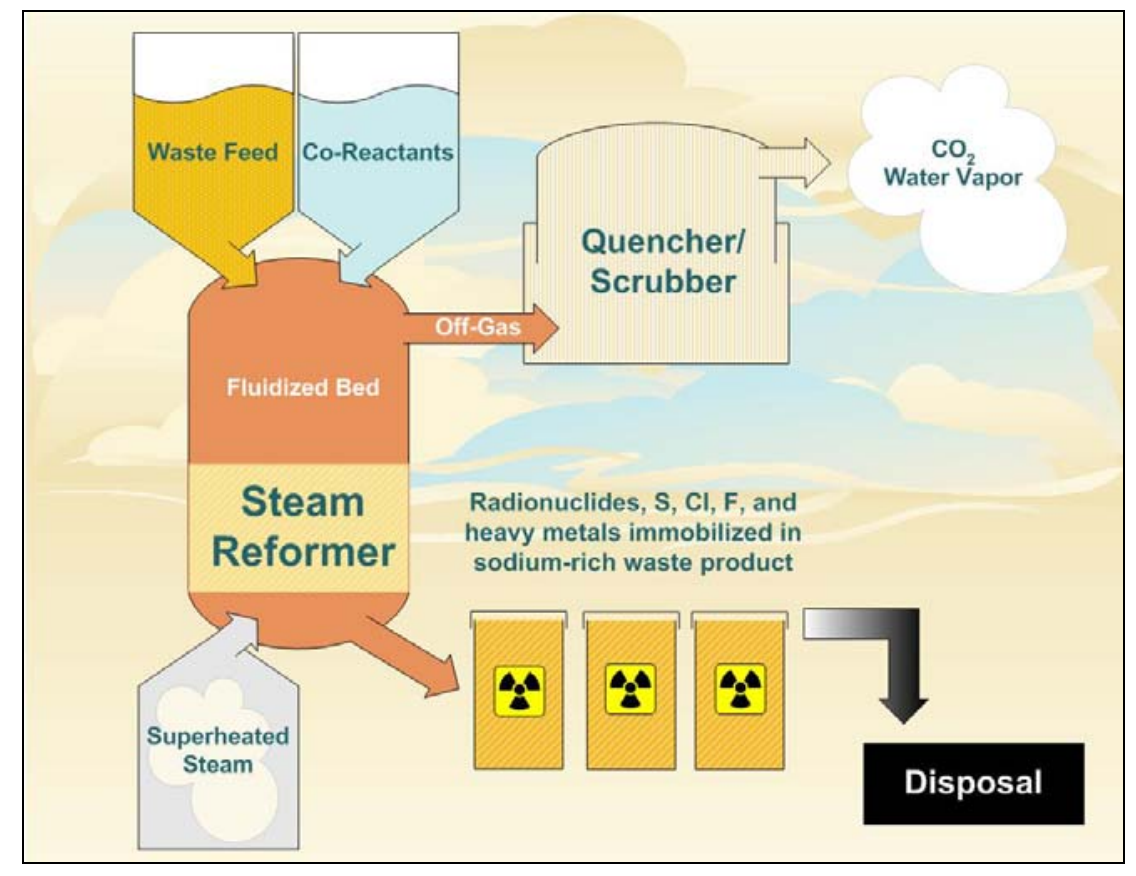

Fig. 1. THOR ${ }^{\mathrm{SM}}$ fluidized bed steam reforming process

The THOR ${ }^{\mathrm{SM}}$ steam reforming process chemistry is summarized as follows:

- Nitrates and nitrites are directly reduced to nitrogen gas with less than $300 \mathrm{ppm}$ of NOx present in the off-gas from the fluid bed and less than 50 ppm NOx in the process stack;

- Sodium, potassium, and aluminum in the waste feed are converted to a stable, water insoluble mineral product, e.g. mostly Nepheline and Sodalite, $\mathrm{Na}_{2} \mathrm{O}-\mathrm{Al}_{2} \mathrm{O}_{3}-2 \mathrm{SiO}_{2}(\mathrm{Na}-\mathrm{Al}-$ $\mathrm{Si}$ ), that has a $\mathrm{Na}_{2} \mathrm{O}$ loading of greater than $19 \%$ by weight;

- Sulfates, chlorides, and fluorides in the waste feed are bound as a part of the Nepheline mineral structure so that less than $5 \%$ is volatized to the off-gas;

- Radionuclides in the waste feed are retained $(>99.9 \%)$ in the solid, mineralized product, with the exception of tritium, carbon ${ }^{14}$, and iodine that are largely volatized;

- The mineralized product will pass the Toxicity Characteristic Leaching Procedure (TCLP) test Uniform Treatment Standard (UTS) limits for heavy metals, and has less than $10 \mathrm{ppm}$ residual nitrates and nitrites; and

- An optional sodium carbonate, $\mathrm{Na}_{2} \mathrm{CO}_{3}$, product can be produced that can be directly vitrified in a joule-heated melter due to its low melting point $\left(\sim 845^{\circ} \mathrm{C}\right)$.

(C) THOR Treatment Technologies, LLC, 2002. All Rights Reserved Published with the express permission of THOR Treatment Technologies. 


\section{PROCESS TECHNOLOGY OVERVIEW}

$\mathrm{Na}-\mathrm{Al}-\mathrm{Si}$ is the preferred final waste product for applications that require waste immobilization without vitrification or grouting. For sites that require burial of only immobilized monolithic solids, the monolithic Na-Al-Si form can be produced. For wastes that must be vitrified, the preferred product is sodium carbonate, which can be readily vitrified in joule-heated melters. The sodium carbonate product can be provided in the dry granule/powder form or as an aqueous solution and/or slurry for feed to a vitrification melter or to a grout facility. The granular/powder forms of Na-Al-Si and sodium carbonate are suitable for direct disposal at the Waste Isolation Pilot Plant (WIPP).

The following sections of this technical overview provide discussions of process chemistry in the steam reformer, reduction of nitrates to nitrogen, conversion of alkali metals to stable mineral form, neutralization of acid gases, removal of solids carryover from the reformer, destruction of RCRA and TSCA organics, reduction and immobilization of hazardous metals, and finally, secondary process waste generation, emissions, and discharges. Figure 2 provides a process flow diagram for the $\mathrm{THOR}^{\mathrm{SM}}$ steam reforming process.

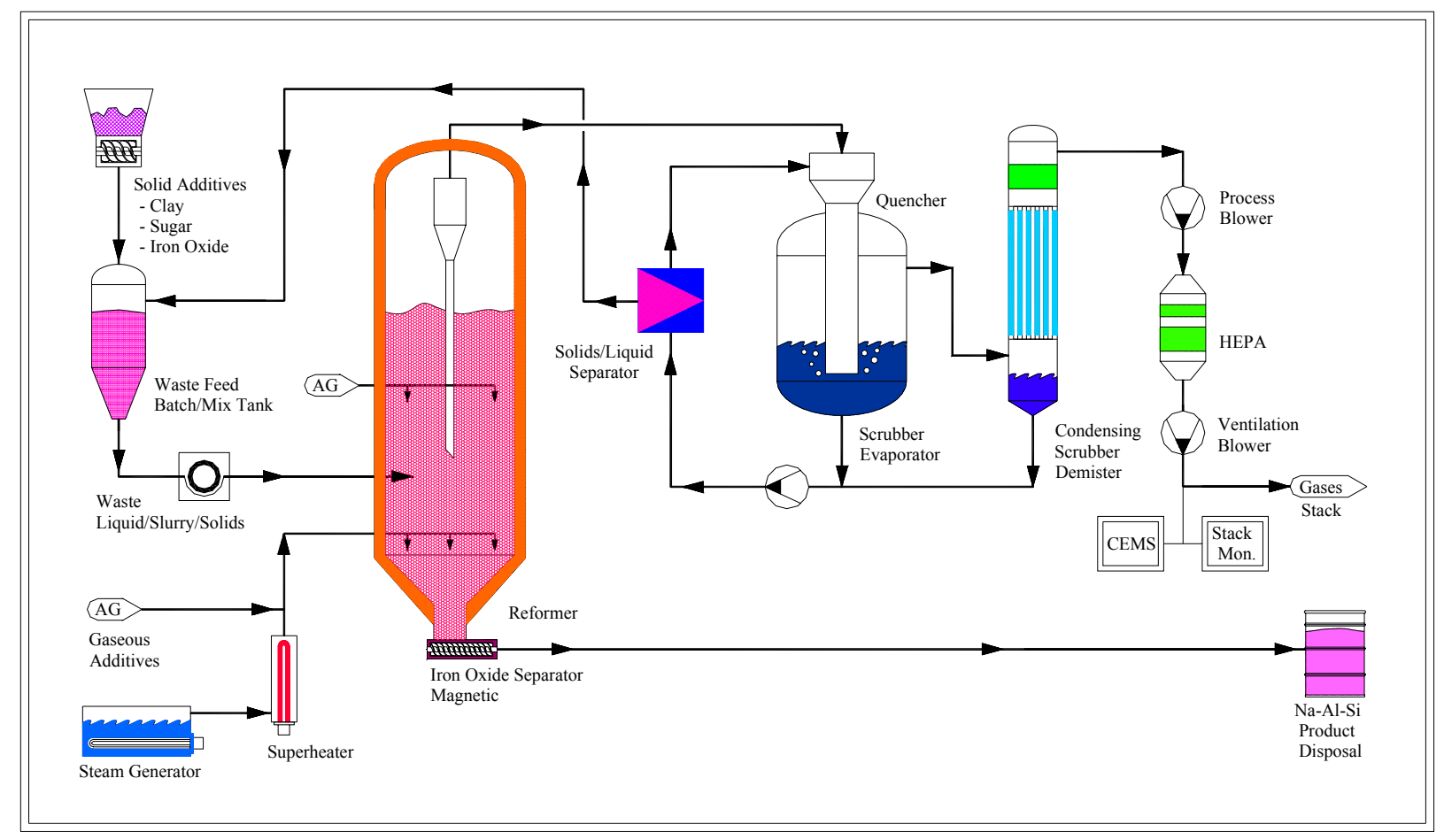

Fig. 2. Flow diagram of the $\mathrm{THOR}^{\mathrm{SM}}$ steam reforming process

\section{PROCESS CHEMISTRY IN THE STEAM REFORMER}

In the steam reformer, the granular/particle bed material is fluidized with low pressure superheated steam. The tank waste is mixed in a batch/feed tank with select co-reactants, including a mineralization additive (clay). The waste feed/co-reactant slurry is injected into the

(C) THOR Treatment Technologies, LLC, 2002. All Rights Reserved Published with the express permission of THOR Treatment Technologies. 
bottom of the fluidized bed just above the fluid gas (steam) distributors. Additional solid coreactants, such as granular carbon and iron oxide reductants, are present in the fluid bed. The lower zone of the fluid bed is operated in strongly reducing conditions to facilitate high reduction of nitrates and nitrites to nitrogen gas. The upper zone of the fluid bed is operated under oxidizing condition by injection of oxygen into the upper zone of the fluidized bed. The oxidizing zone converts residual carbon reductants and organics into carbon dioxide and water vapor. Several chemical and physical reactions take place in the steam reformer:

- All liquids are evaporated.

- Sodium, potassium, and aluminum in the waste feed are converted into a stable mineralized product, Na-Al-Si, which contains essentially all the radionuclides and inorganic elements in the waste feed stream.

- Nitrates and nitrites in the waste feed are converted into nitrogen gas by the carbon and metal reductant solids and $\mathrm{CO}$ and $\mathrm{H}_{2}$ gases in the bed.

- Organics are initially converted into light volatile hydrocarbons such as methane, carbon monoxide, hydrogen, carbon dioxide, and water in the lower zone of the reformer bed. In the upper zone of the reformer bed, oxygen is injected to more fully oxidize the gaseous constituents. The off-gas stream from the reformer consists of water vapor, carbon dioxide, nitrogen, fine particles of solid product, minor carbon particle carryover, and small quantities of acid gases not converted to a mineralized form in the reformer.

- Certain hazardous metals are reduced to a non-hazardous valence state (e.g., $\mathrm{Cr}(\mathrm{VI})$ is reduced to $\mathrm{Cr}$ (III) and are chemically bound in the solid product. Other hazardous metals, such as lead, are also chemically bound in the solid Na-Al-Si product.

The steam reformer is operated under vacuum at $700^{\circ} \mathrm{C}$ to $750^{\circ} \mathrm{C}$ and can be electrically heated (small units) or operated in an auto-thermal mode, whereby the energy needs are supplied by the incoming superheated steam and by the oxidation of organics from the waste and carbon reductants. For production scale units, auto-thermal steam reforming is the preferred mode of operation.

\section{NITRATE REDUCTION TO NITROGEN GAS}

Substantial research has been performed by many organizations over the past 50 years to develop an efficient nitrate destruction process. Studsvik developed the $\mathrm{THOR}^{\mathrm{SM}}$ steam reforming technology to provide unparalleled performance with the following demonstrated results:

- Residual nitrate content in the reformed solid waste product is $<10 \mathrm{ppm}$,

- Direct conversion of $>99 \%$ of nitrates and nitrites in the waste feed to nitrogen gas, and

- Total NOx in off-gas from reformer is $<300 \mathrm{ppm}$ with $<50 \mathrm{ppm}$ NOx in the off-gas at the stack.

The above referenced high conversion of nitrates to nitrogen requires that several specific features and reactions be incorporated into a single step thermal process: 1) fluidized bed material with high surface area and high heat transfer capability, 2) high energy generation to evaporate and superheat the water in the typical waste feed, 3) strongly reducing condition that is provided by the carbonaceous and metal-based reductants, 4) superheated steam that generates

(C) THOR Treatment Technologies, LLC, 2002. All Rights Reserved Published with the express permission of THOR Treatment Technologies. 
carbon monoxide and hydrogen inside the bed from the reaction of steam with the carbon reductant(s), and 5) co-reactant(s) that convert the alkali metals ( $\mathrm{Na}$ and $\mathrm{K}$ ) into higher melting point mineral compounds to prevent formation of low melting point eutectic salts and unwanted bulk agglomerations in the fluid bed.

The fluidized bed material can include ceramic media and/or reformed product granules/powders. The incoming waste feed coats the fluidized particles and is instantly dried. The large active surface of dried nitrates readily reacts with the hot carbon reductant particles, carbon monoxide and hydrogen gases, and the reduced metal and metal oxides particles in the fluidized bed.

Experience has shown that thermal denitration without the presence of a reductant will result in reduction of residual nitrates in the solid product of only up to $90 \%$, i.e. $90 \%$ of the incoming nitrates are thermally volatized leaving approximately $10 \%$ of incoming nitrates in the final solid waste product. The typical total NOx content of other thermal denitration processes, without use of a reductant, will range from 20,000 ppm to over 50,000 ppm total NOx in the process off-gas. The addition of carbonaceous reductants to nitrate wastes in a thermal denitration process has shown substantial improvements with up to $98 \%$ nitrate reduction in the solid product and a corresponding reduction of total NOx in the process off-gas to $3,000 \mathrm{ppm}$ to $10,000 \mathrm{ppm}$. A further order of magnitude improvement in nitrate conversion is possible by use of both carbonaceous and metal-based reductants in the fluid bed. The presence of low-cost metal oxides, e.g. iron oxide particles, in the fluid bed results in the unexcelled performance of the $\mathrm{THOR}^{\mathrm{SM}}$ process for effective reduction of NOx in the off-gas and only trace levels of residual nitrates in the solid reformed product, as summarized above.

\section{ALKALI METAL CONVERSION TO MINERAL FORM}

The THOR ${ }^{\mathrm{SM}}$ steam reforming process has the unique capability to convert alkali metals, Na and $\mathrm{K}$, into stable minerals in the fluid bed. The presence of alkali metals in fluid beds has historically proven to be a serious operational problem as sodium and potassium form a variety of low melting point salts with sulfate, chloride, silica, borate, and many other inorganic materials found in typical tank wastes. These low melting point salts combine to form eutectic mixtures that generally melt at much lower temperatures than the pure compounds. The presence of eutectic compounds in a fluid bed usually results in the formation of bulk agglomerations as the melted salts tend to bind the fluidized media particles into larger and larger pieces.

Studsvik has performed intensive work in developing and proving that the addition of selected inorganic co-reactants to a fluid bed can prevent the formation of low melting point eutectic compounds. Certain inorganic co-reactants preferentially substitute for the typical low melting point anions of the $\mathrm{Na}$ and $\mathrm{K}$ salts. The preferred co-reactants include $\mathrm{Ca}, \mathrm{Mg}, \mathrm{Al}$, and $\mathrm{P}$ compounds that combine with alkali metals to form synthetic naturally occurring minerals as listed below (Note - only the main elemental constituents are shown for simplicity).

- Nepheline, Na-Al-Si

- Nosean, Na-Al-Si-SO 4

(C) THOR Treatment Technologies, LLC, 2002. All Rights Reserved Published with the express permission of THOR Treatment Technologies. 
- Fairchildite, $\mathrm{K}-\mathrm{Ca}-\mathrm{CO}_{3}$

- Natrofairchildite, $\mathrm{Na}-\mathrm{Ca}-\mathrm{CO}_{3}$

- Dawsonite, $\mathrm{Na}-\mathrm{Al}-\mathrm{CO}_{3}$

- Eitelite, $\mathrm{Na}-\mathrm{Mg}-\mathrm{CO}_{3}$

- Maricite, $\mathrm{Na}-\mathrm{Fe}-\mathrm{PO}_{4}$

- Buchwaldite, $\mathrm{Na}-\mathrm{Ca}-\mathrm{PO}_{4}$

- Bradleyite, $\mathrm{Na}-\mathrm{Mg}-\mathrm{PO}_{4}-\mathrm{CO}_{3}$, and

- Other similar mineral variations numbering into the hundreds.

The generation of water-insoluble sodium/potassium/aluminum products is preferred, however, most sodium and potassium compounds are water-soluble, e.g. sodium carbonate, sodium aluminate, etc. The water-soluble sodium compounds will generally require further stabilization (grouting, solidification, vitrification, etc.) prior to disposal to prevent water dissolution of the buried product into the ground water. Therefore, the generation of water-insoluble sodium products is very desirable. For this reason, the preferred products are the water-insoluble species such as Nosean and Nepheline. The Nepheline, Nosean, and related sodium-alumina-silicate (Sodalite) compounds form a crystalline, cage-like structure that has the ability to substitute and bind large atoms (such as Cesium, Technetium, and other radionuclides and heavy metals) within the crystalline structure to produce a highly leach-resistant product. The Na-Al-Si compounds have demonstrated TCLP leaching that is substantially lower than the Land Disposal Restrictions (LDR) Universal Treatment Standard (UTS) limits for heavy metals.

In order to generate the alkaline earth mineralized compounds mentioned above, the following co-reactants can be utilized, each co-reactant would be added in the proportions needed to generate the desired higher melting point compound, and/or water-insoluble compounds. Figure 3 provides typical simplified reaction equations for formation of the main mineralized products.

- Addition of lime $(\mathrm{CaO})$ or other $\mathrm{Ca}$ compound such as calcium carbonate or nitrate could provide conversion of alkaline earths to $\mathrm{Ca}$ rich final product, e.g Natrofairchildite. The carbonate is provided by the $\mathrm{CO}_{2}$ generated by the reduction of nitrates and reformation and oxidation of carbon reductants in the fluid bed.

- Addition of magnesia $(\mathrm{MgO})$ would produce minerals rich in magnesia, e.g. Eitelite.

- Addition of clays (alumina-silicates such as kaolin, bentonite, etc) to produce a Nepheline, Nosean or other related sodium-alumina-silicates. Clays are considered to be aluminum compounds.

- Addition of only $\mathrm{Al}$ compounds including: aluminum nitrate, $\mathrm{Al}\left(\mathrm{NO}_{3}\right)_{3}$, aluminum hydroxide or tri-hydrate $\mathrm{Al}(\mathrm{OH})_{3}$, aluminum metal particles, etc. will produce a sodium-aluminate compound. Aluminum nitrate has been used by the DOE INEEL calciner for many years to produce sodium aluminate in an oxidizing fluid bed with no reducing zone. Aluminum hydroxide is used by Studsvik at the Studsvik Processing Facility (SPF) in Erwin, TN to produce sodium aluminate rich products in a reducing environment.

- Addition of phosphate compounds produces bonded ceramic minerals such as Maricite, Buchwaldite, Bradleyite or other $\mathrm{PO}_{4}$ containing compounds. For waste feeds containing phosphate compounds, such as tri-butyl phosphate, etc, the final solid product would be an inorganic phosphate as listed above.

(C) THOR Treatment Technologies, LLC, 2002. All Rights Reserved Published with the express permission of THOR Treatment Technologies. 
- Addition of silica compounds produces a sodium silicate product.

- Addition of no solid co-reactant will yield sodium carbonate product. Sodium will combine with carbon dioxide in the reformer gases to provide a sodium carbonate product. The generation of sodium carbonate in this type of application has been known since the 1950s in test fluid bed denitration systems.

$$
\begin{array}{lll}
\mathrm{Na}+\mathrm{Al}_{2} \mathrm{O}_{3}-2 \mathrm{SiO}_{2} \text { (Clay) } & = & \mathrm{Na}_{2} \mathrm{O}-\mathrm{Al}_{2} \mathrm{O}_{3}-2 \mathrm{SiO}_{2} \\
\mathrm{Na}+\mathrm{K}+\mathrm{Al}_{2} \mathrm{O}_{3}-2 \mathrm{SiO}_{2} \text { (Clay) } & = & \mathrm{NaKO}_{2} \mathrm{Al}_{2} \mathrm{O}_{3}-2 \mathrm{SiO}_{2} \\
\mathrm{Na}+\mathrm{SO}_{4}+\mathrm{Al}_{2} \mathrm{O}_{3}-2 \mathrm{SiO}_{2} \text { (Clay) } & = & \mathrm{Na}_{2} \mathrm{SO}_{4}-\mathrm{Al}_{2} \mathrm{O}_{3}-2 \mathrm{SiO}_{2} \\
\mathrm{Na}+\mathrm{Cl}+\mathrm{Al}_{2} \mathrm{O}_{3}-2 \mathrm{SiO}_{2} \text { (Clay) } & = & \mathrm{NaCl}-\mathrm{Al}_{2} \mathrm{O}_{3}-2 \mathrm{SiO}_{2} \\
\mathrm{Na}+\mathrm{F}+\mathrm{Al}_{2} \mathrm{O}_{3}-2 \mathrm{SiO}_{2} \text { (Clay) } & = & \mathrm{NaF}-\mathrm{Al}_{2} \mathrm{O}_{3}-2 \mathrm{SiO}_{2} \\
\mathrm{Na}+\mathrm{Al}_{2} \mathrm{O}_{3}+\mathrm{SiO}_{2} \text { (Silica) } & = & \mathrm{Na}_{2} \mathrm{O}-\mathrm{Al}_{2} \mathrm{O}_{3}-2 \mathrm{SiO}_{2}
\end{array}
$$

Fig. 3. Steam reformer chemistry converts sodium, potassium, aluminum, sulfates, chlorides, fluorides, and radionuclides into sodium-alumina-silicates

\section{DESTRUCTION OF RCRA AND TSCA ORGANICS}

The THOR ${ }^{\mathrm{SM}}$ steam reforming process destroys organics in the wastes including any RCRA and TSCA organic constituents. Specifically, the process destroys RCRA organic waste codes D018 through D043 and F001 through F005 and TSCA-listed PCBs. The THOR ${ }^{\mathrm{SM}}$ process is a nonincineration thermal treatment system.

The organics are initially volatized and steam reformed into carbon monoxide, hydrogen and a small quantity of light hydrocarbons, such as methane and ethylene. The light hydrocarbons and the carbon monoxide and hydrogen gases generated from the steam reformation of carbon and organic materials are further oxidized to carbon dioxide and water vapor by addition of oxygen to the fluidizing gases in the upper oxidizing zone of the reformer bed.

The formation of dioxin and furan compounds has been studied by the DOE for a steam reforming process that has similar organic destruction capability as the THOR ${ }^{\mathrm{SM}}$ process. The results of the extensive organic destruction demonstration program (DOE Contract No. DEAR21-95MC32091 with Thermo-Chem, 1995) confirm that dioxins and furans are not generated in the steam reformer and typical off-gas systems. Indeed, any dioxins or furans in the waste feed can also be destroyed in the reformer systems.

(C) THOR Treatment Technologies, LLC, 2002. All Rights Reserved Published with the express permission of THOR Treatment Technologies. 


\section{NEUTRALIZATION OF ACID GASES AND REMOVAL OF SOLIDS CARRYOVER FROM OFF-GAS}

Testing on Hanford LAW surrogates has shown that over $95 \%$ of the sulfur compounds, fluorides and chlorides in the waste feed react in the steam reformer with the clay co-reactant and become an integral part of the final Na-Al-Si waste product crystalline structure. A small amount of the $\mathrm{S}, \mathrm{Cl}$, and $\mathrm{F}$ in the incoming waste feed forms volatile acid gases, which pass through the steam reformer and are neutralized in the downstream off-gas quencher/scrubber. The quencher/scrubber instantly cools the hot reformer off-gases, and any residual acid gases in the reformer off-gas are adsorbed by the scrubber water solution. The scrubber solution is neutralized by the injection of metered quantities of caustic materials. Typical caustic neutralization agents can be sodium hydroxide $(\mathrm{NaOH})$, lime $(\mathrm{CaO})$, or magnesia $(\mathrm{MgO})$.

The quencher/scrubber and downstream condenser and demister also function to remove product fines carried over from the reformer. The low volume product fines and neutralized acid gas salts removed by the scrubber system are periodically returned to the reformer waste feed tank as a recycle stream for incorporation into the solid reformer product.

\section{IMMOBILIZATION OF HAZARDOUS METALS}

The strong reducing environment in the steam reformer converts certain hazardous heavy metals to non-hazardous valence states. For example, $\mathrm{Cr}(\mathrm{VI})$ is reduced to $\mathrm{Cr}(\mathrm{III})$ and is incorporated into the Na-Al-Si product. In addition, virtually all of the lead that enters the reformer is chemically bound up in the Na-Al-Si product as well. The Na-Al-Si product has been shown to pass the TCLP test easily meeting the LDR UTS limits for leachability by a factor of 10 to 100 .

Additional work is needed to determine the final performance of the $\mathrm{THOR}^{\mathrm{SM}}$ process on other heavy metals. Studsvik has had broad experience with processing wastes with $\mathrm{Cr}$ and $\mathrm{Pb}$, however, most commercial Low Level Radioactive Wastes (LLW) do not contain more than trace quantities of other heavy metals. It is expected that other heavy metals will be retained in the solid product with the exception of mercury. If mercury is present in the waste feed, a mercury removal capability will need to be provided in the $\mathrm{THOR}^{\mathrm{SM}}$ off-gas system as mercury will volatize to the gas phase during thermal treatment. It is expected that a commercially available granular activated carbon or gold impregnated media can be placed downstream of the HEPA filter to remove essentially all volatile mercury from the off-gas stream.

\section{SECONDARY WASTE GENERATION, EMISSIONS, AND DISCHARGES}

A significant benefit of the THOR ${ }^{\mathrm{SM}}$ steam reforming process is that the facility produces zeroliquid releases. The Erwin facility has been commercially operational at full-scale for three years with no release of liquids. All water is released as water vapor out the monitored ventilation stack. All organics are processed through the reformer.

The emissions of SOx, HCl, HF, NOx and other regulated pollutants are estimated in Table I. The emissions data presented in Table 1 represent actual readings from the Erwin steam reforming facility CEMS and correlations based on CEMS data from previous bench-scale and

(C) THOR Treatment Technologies, LLC, 2002. All Rights Reserved Published with the express permission of THOR Treatment Technologies. 
pilot-scale demonstration programs performed by Studsvik, including results of nitrate destruction demonstrations.

Table I. Discharges and Emissions from a Production-Scale THOR ${ }^{\mathrm{SM}}$ Steam Reforming Process for Tank Wastes

\begin{tabular}{|c|c|}
\hline Material & Discharge/Emission \\
\hline $\mathrm{SOx}$ & $<10 \mathrm{ppm}$ in off-gas at stack \\
\hline $\begin{aligned} \text { NOx: } & \\
\text { - } & \mathrm{NO}_{2} \\
\text { - } & \mathrm{NO} \\
\text { - } & \mathrm{N}_{2} \mathrm{O}, \text { Others }\end{aligned}$ & $\begin{array}{l}<5 \mathrm{ppm} \text { in off-gas at stack } \\
<25 \mathrm{ppm} \text { in off-gas at stack } \\
<25 \mathrm{ppm} \text { in off-gas at stack }\end{array}$ \\
\hline $\mathrm{HCl}$ & $<10$ ppm in off-gas at stack \\
\hline $\mathrm{HF}$ & $<2 \mathrm{ppm}$ in off-gas at stack \\
\hline $\mathrm{CO}$ & $<25 \mathrm{ppm}$ in off-gas at stack \\
\hline $\begin{array}{l}\text { - Carbon }{ }^{14} \\
\text { - Iodine } \\
\text { - Other }\end{array}$ & $\begin{array}{l}\text { Tritium is converted to water vapor and is released up the monitored } \\
\text { stack. An optional off-gas condenser can be provided to fully } \\
\text { condense water and discharge water and tritium to groundwater if } \\
\text { required. } \\
\text { Carbon }{ }^{14} \text { is converted to carbon dioxide and is released up the } \\
\text { monitored stack. } \\
\text { Iodine will be released up the stack unless adsorption media is placed } \\
\text { downstream of the HEPA filter to remove iodine from the off-gas. } \\
>99.99 \% \text { retained in the solid product }\end{array}$ \\
\hline Mercury & $\begin{array}{l}\text { Mercury is removed from the off-gas by means of adsorption media } \\
\text { downstream of HEPA filters. }\end{array}$ \\
\hline Scrubber Salts & $\begin{array}{l}\text { Scrubber salts are recycled to the reformer waste feed. There are no } \\
\text { scrubber salt solution or dried salt discharges. }\end{array}$ \\
\hline $\mathrm{H}_{2} \mathrm{O}$ & $\begin{array}{l}\text { Water is evaporated and discharged through the plant stack as water } \\
\text { vapor. Process has zero-liquid releases. }\end{array}$ \\
\hline
\end{tabular}

Based on operational experience, the salts generated in the quencher/scrubber from the neutralization of residual volatized acid gases from the reformer would be less than $5 \%$ of the total $\mathrm{S}, \mathrm{Cl}$, and $\mathrm{F}$ in the incoming waste feed. The small amount of acid gases, together with fine product particles carried over from the reformer will be removed by the scrubber system. The neutralized aqueous scrubber solution will be transferred to the reformer waste feed tank. The solids in the scrubber solution, as well as neutralized salts, will be incorporated into the solid product in the reformer.

The only significant gaseous effluents from the THOR ${ }^{\mathrm{SM}}$ process are carbon dioxide and water vapor. Trace radioactive particulates remaining in the off-gas stream after the quencher/scrubber are removed by HEPA filtration prior to discharge of gases to the atmosphere. Volatile radionuclides include tritium, carbon ${ }^{14}$ and iodine. If desired, the iodine can be adsorbed by granular activated carbon media downstream of the HEPA filter. It is not normally feasible to remove the carbon ${ }^{14}$, as it will have been converted to carbon ${ }^{14}$ dioxide and cannot be easily separated from non-radioactive carbon dioxide. The tritium will be converted to water vapor in

(C) THOR Treatment Technologies, LLC, 2002. All Rights Reserved Published with the express permission of THOR Treatment Technologies. 
the process. It is often preferable to release the tritium up the monitored stack versus to the groundwater.

\section{DEMONSTRATION PROGRAM EXPERIENCE}

Studsvik developed the THOR ${ }^{\mathrm{SM}}$ steam reforming process over a period of several years. Extensive bench-scale and pilot-scale test programs were implemented to qualify and optimize the steam reforming process and to make the technology economical, reliable and robust with unsurpassed safety. Five separate demonstration programs have been or are currently in progress specifically for processing nitrate wastes.

Studsvik performed the initial proof-of-process denitration test program concurrent with the qualification test program performed for the Studsvik Processing Facility (SPF). The test was performed using the Studsvik 6" fluid bed system at the Hazen Research facility located in Golden, $\mathrm{CO}$ as shown in Figure 4 below. The test was performed on $5.2 \mathrm{M} \mathrm{NaNO}_{3}$ with sugar, carbon, and iron oxide reductants. The fluid bed operated throughout the entire demonstration run with no in-bed agglomerations, with NOx in the reformer off-gas consistently below 500 ppm. For over half of the test program the NOx levels in the reformer off-gas were $<100 \mathrm{ppm}$. A low volume sodium carbonate product was obtained.

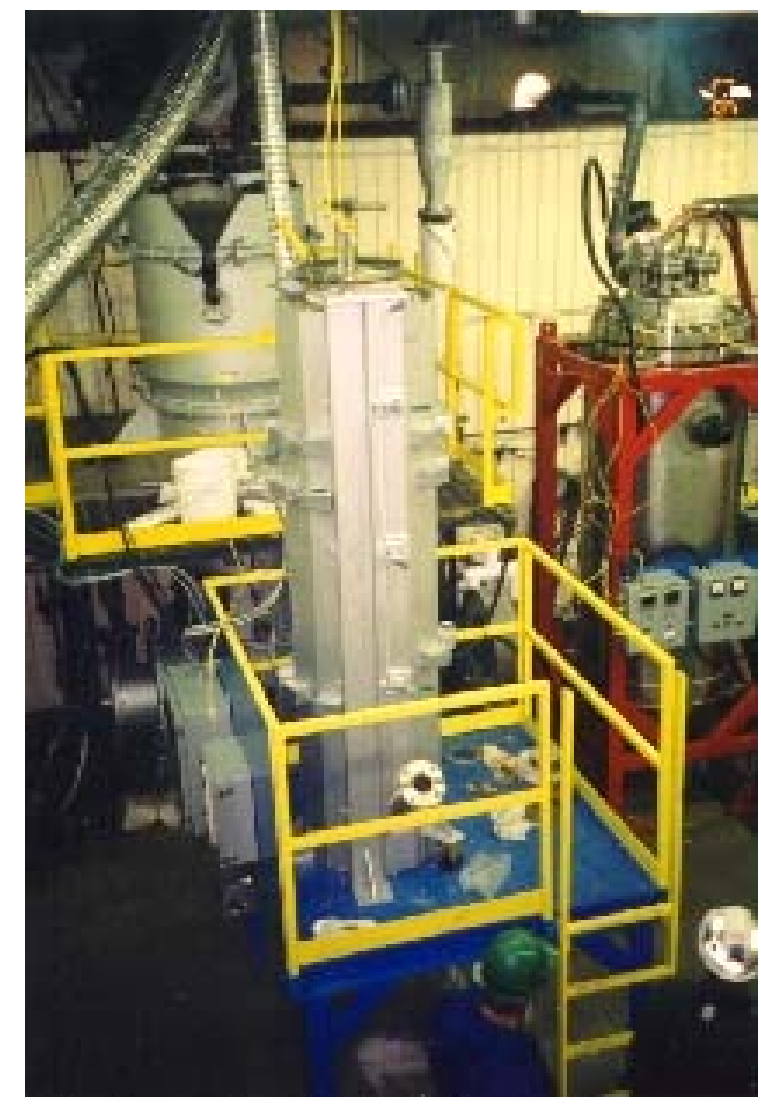

Fig. 4. Pilot-scale fluid bed reformer demonstration system assembly

(C) THOR Treatment Technologies, LLC, 2002. All Rights Reserved Published with the express permission of THOR Treatment Technologies. 
A second test program was performed by Lockheed Martin Idaho Technologies Company (LMITCO) using acidic INEEL sodium bearing waste (SBW) surrogate. The demonstration investigated several changes in operating parameters and use of additives in a small, 3", lab-scale fluid bed system installed at SAIC's STAR facility in Idaho Falls, ID. The final process runs demonstrated high conversion of nitrates to nitrogen with $<500$ ppm NOx in the reformer offgas.

Studsvik performed a third demonstration under contract with Bechtel National Inc. The benchscale demonstration of the THOR ${ }^{\mathrm{SM}}$ process used Hanford LAW surrogate. The Demonstration utilized Studsvik's 6" fluid bed system located at Hazen's facility. The demonstration was performed in November and December 2001. The test results were very positive, with successful operation of the process to generate consistent Na-Al-Si and sodium carbonate products. The off-gas from the process over a several day period confirmed the high nitrate conversion to nitrogen gas with the same results as in the initial Studsvik test.

THOR has been awarded a contract by Bechtel BWXT Idaho, LLC (BBWI) to demonstrate the $\mathrm{THOR}^{\mathrm{SM}}$ steam reforming process using a new 6" fluid bed reforming system installed at SAIC's STAR facility in Idaho Falls, Idaho. This demonstration will be performed in January, 2003 and will operate for approximately 100 hours using an acidic nitric acid-sodium nitrate solution as waste feed. A sodium carbonate product will be produced.

THOR has been awarded a contract by $\mathrm{CH} 2 \mathrm{M}$ Hill Hanford Group to demonstrate the THOR ${ }^{\mathrm{SM}}$ steam reforming process using a new large-scale process plant designed and constructed by THOR. This demonstration is on-going and will provide data needed to implement a production scale processing plant at the Hanford tank farms by mid-2005.

\section{COMMERCIAL RADIOACTIVE WASTE PROCESSING EXPERIENCE}

The Studsvik Processing Facility (SPF) has been in commercial operation processing low-level radioactive waste (LLW) for over three years. The SPF has the capability to safely and efficiently receive and process a wide variety of solid and liquid LLW streams including: ion exchange resins (IER), charcoal, graphite, sludge, oils, solvents, and cleaning solutions with contact radiation levels of up to $400 \mathrm{R} / \mathrm{hr}$. The licensed and heavily shielded SPF can receive and process liquid and solid LLWs with high water and/or organic content, see Figure 5.

The SPF employs the THOR ${ }^{\mathrm{SM}}$ process. The THOR ${ }^{\mathrm{SM}}$ technology is suitable for processing hazardous, mixed, and dry active (DAW) LLW with appropriate licensing and waste feed modifications. The final reformed residue product comprises a non-dispersible, granular solid suitable for long-term storage or direct burial in a qualified container.

(C) THOR Treatment Technologies, LLC, 2002. All Rights Reserved Published with the express permission of THOR Treatment Technologies. 


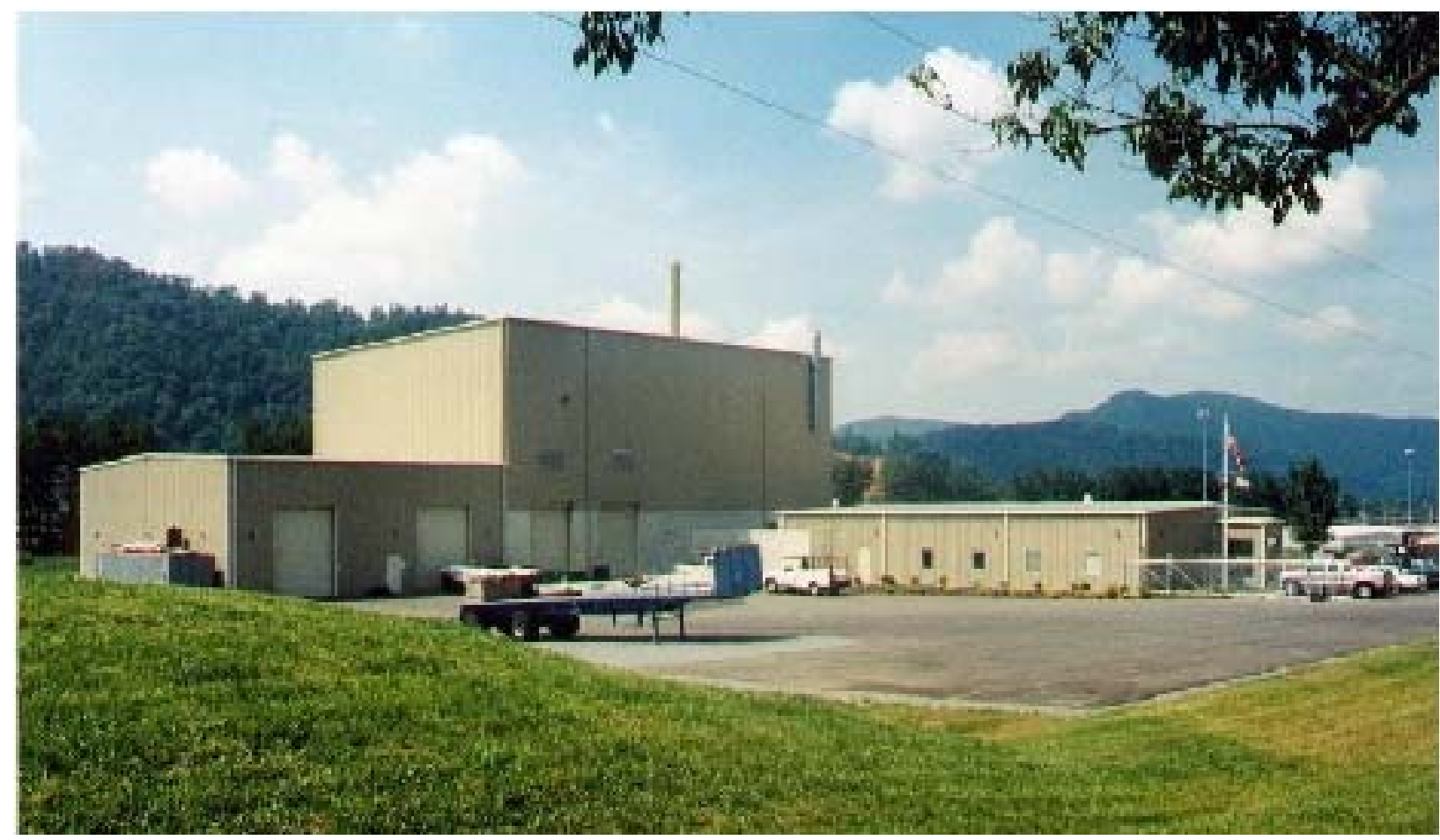

Fig. 5. Studsvik Processing Facility, Erwin, TN

Operations have demonstrated consistent, safe, reliable, robust operating characteristics with volume reductions up to 20:1 and weight reductions up to 15:1 when processing depleted, mixed bed, ion exchange resins, with over $99.8 \%$ of all radionuclides in the waste feed incorporated in the final solid residue product. Over 85,000 cuft of LLW ion exchange resin, oils, aqueous liquids, granular carbon, paper and plastics have been successfully processed for commercial nuclear power plant customers since commencement of commercial operation in July, 1999. A description of the SPF is available on the internet - search for "Studsvik Processing Facility" or visit the Studsvik website.

\section{CONCLUSION}

In summary, the $\mathrm{THOR}^{\mathrm{SM}}$ process has many salient features as listed below:

- Waste feed can include solids, liquids, slurries, and gases

- Acidic and basic tank wastes can be processed without neutralization

- Nitrates and nitrites are destroyed with $<10$ ppm residual nitrates in solid product, $<300$ ppm NOx in reformer off-gas, and $<50$ ppm NOx in off-gas to stack

- $\mathrm{S}, \mathrm{Cl}$, and $\mathrm{F}$ are immobilized in a stable mineral form, with no secondary scrubber solution waste stream and $<10$ ppm SOx, $\mathrm{HCl}$, or $\mathrm{HF}$ in off-gas at stack

- Alkali metals, radionuclides, and non-volatile heavy metals are immobilized in stable, water insoluble, Na-Al-Si mineral form.

- Greater than $99.9 \%$ of radionuclides are incorporated into the solid product. Tritium, carbon $^{14}$, and iodine are generally partitioned to the off-gas.

(C) THOR Treatment Technologies, LLC, 2002. All Rights Reserved Published with the express permission of THOR Treatment Technologies. 
WM '03 Conference, February 23-27, 2003, Tucson, AZ

- Na-Al-Si product meets LDR UTS limits for heavy metal leachability (TCLP test)

- Final solid product can be sodium-alumina-silicate or sodium carbonate in granular/powdered or monolithic form

- Systems operate under vacuum (20-40 inch W.C.)

- Safe shutdown can be accomplished in $<1$ minute

- Reformer contains low inventory of unreacted waste

- Vessels can be drained of contents and decontaminated by acid or water washes to allow contact maintenance on most components

- Facility is zero-liquid release as water vapor is discharged up the stack

- Wastes with high water content, high organic contents, and high sulfate content are efficiently processed

- The THOR ${ }^{\mathrm{SM}}$ process is covered by issued and pending patents, see US Patent No. 6,280,694 and $6,084,147$.

\section{REFERENCES}

1. C. M. JANTZEN, "Engineering Study of the Hanford Low Activity Waste (LAW) Steam Reforming Process (U),” WSRC-TR-2002-00317, Rev. 0, Savannah River Technology Center, July 12, 2002.

(C) THOR Treatment Technologies, LLC, 2002. All Rights Reserved Published with the express permission of THOR Treatment Technologies. 